$\mathrm{A} \int_{\text {ass }} \mathrm{H}$

Article history :

Received : 06.02.2016

Revised : 21.04.2016

Accepted : 01.05.2016
Members of the Research Forum

Associated Authors:

${ }^{1}$ Department of Seed Science and Technology, Horticultural College and Research Institute for Women, TRICHY (T.N.) INDIA

${ }^{2}$ Department of Floriculture, Tamil Nadu Agricultural University, COIMBATORE (T.N.) INDIA
Author for correspondence : G. DILEEP KUMAR Department of Seed Science and

Technology, Tamil Nadu

Agricultural University, COIMBATORE (T.N.) INDIA

Email : dlipagri@gmail.com
THEASIAN JOURNALOF HORTICULTURE

Volume 11 | Issue 1 | June, 2016 | 109-113

Visit us -www.researchjournal.co.in

\section{Green synthesis and characterization of silver (Ag) nanoparticles using neem leaf extract and its antifungal activity against seed borne pathogens in chilli}

\section{G. DILEEP KUMAR, N. NATARAJAN ${ }^{1}$ AND M. DIVYA ${ }^{2}$}

ABSTRACT : The silver nanoparticles (AgNPs) synthesized using hot water neen leaf extract (NLF) as reducing and stabilizing agent are reported and evaluated for antibacterial activity against chilli seed borne pathogens. The effect of extract concentration, contact time, $\mathrm{pH}$ and temperature on the reaction rate and the shape of the Ag nanoparticles were investigated. The data revealed that the rate of formation of the nanosilver size decreased significantly in the basic medium with different concentration ( $1 \mathrm{mM}, 5 \mathrm{mM}$ and $10 \mathrm{mM})$. Synthesized was characterized by UV-vis spectroscopy, X-ray diffraction, scanning electron microscopy (SEM) and transmission electron microscopy (TEM). The nanoparticle synthesis using different concentration of silver nitrate and $5 \mathrm{mM}$ was getting nano sized silver particles AgNPs. The silver nanoparticles were with an average size of 55 to $350 \mathrm{~nm}$ and mostly rod shape. The antifungal activity of synthesized AgNPs was observed in seed health test and different concentration of silver NPs (750 mg, $1000 \mathrm{mg}$ and $1250 \mathrm{mg}$ ) were used for seed health test. The AgNPs at $750 \mathrm{mg}$ concentration significantly inhibited the seed borne pothogens. Thus AgNPs showed broad spectrum antifungal activity at lower concentration and may be a good alternative therapeutic approach in future.

KEY WORDS : Green synthesis, Silver nanoparticles, Neem leaf extract, Antifungal activity

HOW TO CITE THIS ARTICLE : Kumar, G. Dileep, Natarajan, N. and Divya, M. (2016). Green synthesis and characterization of silver ( $\mathrm{Ag}$ ) nanoparticles using neem leaf extract and its antifungal activity against seed borne pathogens in chilli. Asian J. Hort., 11(1) : 109-113, DOI : 10.15740/HAS/ TAJH/11.1/109-113. 